J. Natn. Sci. Coun. Sri Lanka 199220 (1) : $91-98$

\title{
CHEMICAL COMPOSITION AND ENERGY UTILIZATION VALUES OF COMMON SRI LANKAN FEEDSTUFFS FOR GROWING PIGS
}

\section{V: RAVINDRAN}

Department of Animal Science, University of Peradeniya, Peradeniya.

\author{
(Date of receipt : 02 December 1991) \\ (Date of acceptance : 08 July 1992)
}

\begin{abstract}
Thirteen balance trials, each involving eight growing pigs (average body weight, $32 \pm 4 \mathrm{~kg}$ ), were conducted to determine the digestible energy values of commonly available local pig feedstuffs. The digestible energy values ( $\mathrm{Kcal} / \mathrm{g}$ ) of the feedstuffs on an as-fed basis were : maize, 3.64; sorghum, 3.53; rice bran no:1, 2.40; rice bran no:2, 2.09; cassava root meal, 3.69; coconut poonac, 2.54; gingelly poonac, 2.79; soybean meai, 3.16; cassava leaf meal, 2.13; ipil-ipil leaf meal, 1.54; poultry litter, 1.92 and fish meal (imported), 3.01. The energy utilization value of the local fish meal sample could not be determined, owing to its adverse effects on the animals. The proximate composition and mineral contents of the feedstuffs are also reported.
\end{abstract}

\section{Introduction}

Digestible energy (DE) is the widely used term for expressing the available energy in pig feedstuffs. Since available energy content is a major determinant of the nutritive value of a feed, its assessment is of importance for efficient diet formulations.

While composition and energy values of common feeds in the temperate regions are well documented, corresponding data on materials indigenous to the tropics are limited. In Sri Lanka, digestible energy values of local feedstuffs for pigs have never been investigated. With the current interest in expanding the pig industry, such an evaluation would be timely. The aim of the present study was to determine the DE contents of thirteen local feedstuffs used for growing pigs. The composition and mineral profiles of these ingredients were also determined.

\section{Materials and Methods}

\section{Feed Materials}

All samples, except cassava (Manihot esculenta) root meal, cassava leaf meal, ipil-ipil (Leucaena leucocephala) leaf meal and poultry litter were purchased from commercial outlets in Kandy. Cassava root meal, cassava leaf meal and ipil-ipil leaf meal were prepared in bulk using previously reported methods. ${ }^{1-3}$ Poultry litter, about 12 -month old and paddy husk-based, was collected from the deep litter poultry houses of the University Farm. The litter was sun-dried, heaped in a well ventilated room and allowed to mature for four weeks before use. 


\section{Experimental Design}

Thirteen separate balance trials, each involving eight growing, castrated male pigs (average body weight, $32 \mathrm{~kg}$; range, $26-40 \mathrm{~kg}$ ) were conducted. Different experimental designs were employed for the evaluation of energy and protein supplements.

\section{Energy Supplements}

In each trial, eight pigs were grouped into two blocks based on body weight and the ouiccme groups were assigned to either a basal diet or a test diet. The basal diets consisted of $75 \%$ maize, $16 \%$ soybean meal, $5 \%$ fish meal plus $4 \%$ mineral and vitamin supplements, and supplied $16 \%$ crude protein. The test diet was formulated by replacing $(w / w)$ the basa! diet with $30 \%$ test feedstuff.

A 2 X 2 Latin Square change-over design was exnployed. Each experimental period consisted of an adjustrient period ( 5 days), a preliminary period ( 5 days) and a total collection perioc' (10 days). Thus each trial was of 40 -day duration. By the conclusion of the trial, each diet has been fed to all eight pigs.

\section{Protein Supplements}

Since evaluation of high-protein feedstuffs at dietary levels far in excess of normal levels of use may underestimate their energy utilization values, ${ }^{4}$ a modified design was used for the protein supplements. In each trial, eight pigs were assigned to four outcome groups based on litter and body weight. The outcome groups were then allocated either to a basal diet (similar to that used for evaluation of energy supplements) or to one of the three test diets where the basal diet was replaced (w/w) with $6.6,13.3$ and $20 \%$ of the test feedstuff. The only exception was fish meal, where the replacement levels employed were $3.3,6.6$ and $10 \%$.

A 4 X 4 Latin Square change-over disign was utilized. Each experimental period consisted of an adjustment period ( 5 days), preliminary period ( 5 days) and a total collection period ( 5 days). Each trial therefore lasted 60 days. By the conclusion of the trial, each diet had been fed to all eight pigs.

\section{Experingental Procedare}

Pigs were housed in individual metabolic cages which had facilities for separation and collection of faeces and urine. Diring the adjustment period, after being put into the cages, only the basal diet was given. During the preliminary period, the dietary treatments were introduced and the pigs were fed twice daily with an amount calculated at $5 \%$ of their body weight. All diets were fed in a wet mash form $(1: 1$ feed:water ratio). During the collection period, faeces were collected daily from each cage, dried at $60^{\circ} \mathrm{C}$ for 48 hours and weighed. Faecal and feed samples were bulked, 
ground to pass through a 60-mesh screen and representative samples were taken for the determination of gross energy by calorimetry.

The analyses on feed samples were conducted according to the methods of the Association of Official Analytical Chemists. ${ }^{5}$ Cations were determined by Atomic Absorption Spectrophotometry and phosphorus by colorimetry, as described previously. 6

\section{Statistical Analysis}

Digestible energy contents of the energy supplements were calculated by the difference method, whereas regression analysis vas employed for the protein supplements. ${ }^{7}$ These calculations assumed that there were no associative effects between the basal diet and the test ingredient.

\section{Results and Discussion}

The chemical composition of the test feedstuffs are presented in Table 1 . The average values of cereals, cassava root meal and imported fish meal are comparable to those documented by Gohl, ${ }^{8}$ but differences were observed for the composition of by-product feeds. Rice bran, coconut poonac and gingelly poonac samples were found to contain relatively lower contents of crude protein and higher contents of crude fibre than those reported from elsewhere in the tropics. ${ }^{8}$

Table 1: Percentage chemical composition of the feedstuffs

\begin{tabular}{|c|c|c|c|c|c|c|}
\hline Feedstuff & $\begin{array}{l}\text { Dry } \\
\text { matter }\end{array}$ & $\begin{array}{l}\text { Crude } \\
\text { protein* }\end{array}$ & $\begin{array}{l}\text { Crude } \\
\text { fat* }^{*}\end{array}$ & $\begin{array}{l}\text { Crude } \\
\text { fibre* }\end{array}$ & Ash* & $\begin{array}{l}\text { Nitrogen } \\
\text { free- } \\
\text { extracts* }\end{array}$ \\
\hline
\end{tabular}

\section{Energy supplements}

$\begin{array}{lrrrrrr}\text { Maize } & 92.0 & 9.2 & 4.0 & 2.3 & 1.5 & 83.0 \\ \text { Sorghum } & 91.8 & 10.1 & 4.2 & 2.2 & 2.0 & 81.3 \\ \text { Rice bran no.1 } & 90.1 & 13.2 & 12.8 & 16.0 & 15.0 & 43.0 \\ \text { Rice bran no. } & 89.3 & 8.8 & 11.7 & 19.6 & 23.4 & 36.5 \\ \text { Cassava root meal } & 88.6 & 2.5 & 0.8 & 1.8 & 2.0 & 92.9\end{array}$

Protein supplements

Coconut poonac

Gingelly poonac

$91.2 \quad 21.6$

12.2

7.1

52.1

Soybean meal

89.5

32.5

8.2

14.8

10.8

33.7

Cassava leaf meal

92.0

6.0

8.0

5.6

38.0

Ipil-ipil leaf meal ।

90.3

21.4

6.1

20.2

7.8

44.5

Poultry litter

90.1

4.8

8.1

47.1

Fish meal (imported)

89.3

24.8

3.4

17.8

18.0

36.5

Fish meal (local)

86.9

70.6

4.6

17.3

13.2

11.8

* per cent of dry weight

$\begin{array}{lll}6.5 & 4.0 \quad 24.6\end{array}$

22.4 
The mineral contents of the feedstuffs are presented in Table 2. The calcium and phosphorus contents of the feedstuffs are very similar to those reported elsewhere. ${ }^{8-10}$ Data reported in the literature for the trace mineral contents of feedstuffs are often variable, since significant differences can arise depending on soil and climatic conditions. The high levels of iron determined in all ingredients are probably reflective of contamination during post-harvest processing. Feedstuffs originating from plant materials contained very low levels of calcium, with the exception of gingelly poonac and the two leaf meals. These three feedstuffs were also found to be rich sources of trace minerals. The data also highlight the potential usefulness of poultry litter as a mineral supplement. Poultry litter contained 5.26\% calcium, $2.40 \%$ phosphorus and rather high levels of trace minerals.

Table 2: Mineral contents of the feedstuffs (\% dry matter basis)

\begin{tabular}{|c|c|c|c|c|c|c|c|c|c|}
\hline \multirow[t]{2}{*}{ Feedstuff } & \multicolumn{5}{|c|}{$\mathrm{g} / 100 \mathrm{~g}$} & \multicolumn{4}{|c|}{$\mathrm{mg} / \mathrm{kg}$} \\
\hline & $\mathrm{Ca}$ & $\mathrm{Mg}$ & $\mathrm{K}$ & $\mathrm{Na}$ & $\mathrm{P}$ & $\mathrm{Cu}$ & $\mathrm{Mn}$ & $\mathrm{Zn}$ & $\mathrm{Fe}$ \\
\hline Maize & .03 & .10 & .26 & .01 & .22 & 3 & 14 & 10 & 160 \\
\hline Sorghum & .04 & .12 & .30 & .04 & .29 & 6 & 15 & 12 & 112 \\
\hline Rice bran no:1 & .07 & .10 & 1.36 & .02 & 1.19 & 7 & 18 & 28 & 240 \\
\hline Rice bran no:2 & .04 & .11 & 1.25 & .02 & 1.08 & 4 & 12 & 22 & 286 \\
\hline Cassava root meal & .03 & .06 & .40 & .02 & .18 & 2 & 6 & 10 & 102 \\
\hline Coconut poonac & .09 & .37 & 1.90 & .08 & .55 & 3 & 7 & 20 & 165 \\
\hline Gingelly poonac & 2.14 & .46 & 1.38 & .05 & 1.29 & 16 & 46 & 98 & 237 \\
\hline Soybean meal & .27 & .33 & 2.10 & .04 & .72 & 14 & 22 & 45 & 176 \\
\hline Cassava leaf meal & 1.44 & .31 & 1.96 & .07 & .33 & 12 & 31 & 26 & 488 \\
\hline Ipil-ipil leaf meal & 1.24 & .26 & 1.70 & .06 & .25 & 8 & 20 & 26 & 376 \\
\hline Poultry litter & 5.26 & .48 & 2.74 & .44 & 2.40 & 44 & 248 & 286 & 360 \\
\hline $\begin{array}{l}\text { Fish meal } \\
\text { (imported) }\end{array}$ & 3.02 & .29 & 1.01 & 1.10 & 2.36 & 9 & 22 & 86 & 268 \\
\hline $\begin{array}{l}\text { Fish meal } \\
\text { (local) }\end{array}$ & 4.36 & .26 & 1.20 & 12.36 & 2.18 & 6 & 16 & 55 & 290 \\
\hline
\end{tabular}

Values for dry matter digestibility, gross energy and DE of the feedstuffs are shown in Table 3. The DE contents of maize and sorghum were determined to be 3.64 . and $3.53 \mathrm{Kcal} / \mathrm{g}$, respectively. These values were remarkably similar to those reported by Allen ${ }^{9}$ and NRC $^{10}$ for samples from North America. Over $85 \%$ of the dry matter as well as energy contained in both cereals were digested by growing pigs. Somewhat similar DE contents of maize and sorghum are of some practical relevance in Sri Lanka as sorghum, owing to its drought tolerant ability, can be grown under solely rain-fed conditions to produce moderately good grain yields in areas where maize cannot be successfully cultivated. 
Table 3: Dry matter digestibility (DMD), digestible energy (DE) and energy digestibility of the feedstuffs for growing pigs.

\begin{tabular}{lllll}
\hline Feedstuff & DMD & $\begin{array}{l}\text { Gross } \\
\text { energy } \\
(\mathrm{Kcal} / \mathrm{g})^{*}\end{array}$ & $\begin{array}{l}\text { DE } \\
(\mathrm{Kcal} / \mathrm{g})^{*}\end{array}$ & $\begin{array}{l}\text { Digestibility } \\
\text { of energy }(\%)\end{array}$ \\
\hline
\end{tabular}

\section{Energy supplements}

$\begin{array}{lllll}\text { Maize } & 88 & 4.18 & 3.64 \pm 0.24^{* *} & 87 \\ \text { Sorghum } & 87 & 4.10 & 3.53 \pm 0.21 & 86 \\ \text { Rice bran no.1 } & 64 & 3.71 & 2.40 \pm 0.33 & 65 \\ \text { Rice bran no.2 } & 59 & 3.60 & 2.09 \pm 0.25 & 58 \\ \text { Cassava root meal } & 89 & 4.08 & 3.69 \pm 0.09 & 90\end{array}$

\section{Protein supplements}

Coconut poonac

Gingelly poonac

Soybean meal

Cassava leaf meal

Ipil-ipil leaf meal

Poultry litter

Fish meal (imported)
63

69

82

55

46

56

84
4.22

4.12

4.18

4.10

4.03

3.70

3.96
$2.54 \pm 0.17$

$2.79 \pm 0.15$

$3.16 \pm 0.20$

$2.13 \pm 0.26$

$1.54 \pm 0.36$

$1.92 \pm 0.27$

$3.0 \pm \pm 0.10$
60

68

76

52

38

52

*

As fed-basis

Mean \pm standard error.

In Sri Lanka, large quantities of rice milling by-products are available for use in local animal feed mixtures. Unfortunately, due to inefficient milling techniques, more than $50 \%$ of the by-products processed in Sri Lanka are unsuitable for non-ruminant feeding. Most rice mills currently in use are of the out-moded huller type which removes both the husk and the bran in one operation, thus producing a bran with considerable admixture of husk. This is reflected by the high fibre and ash contents in the bran samples available in local feed market as rice bran no.1 and rice bran ro. 2 (Table 1). The DE contents of rice bran no.1 and no.2 samples were determinec to be 2.40 and $2.09 \mathrm{Kcal} / \mathrm{g}$, respectively. Only $58-65 \%$ of the energy contained in rice bran was digested by pigs. Digestible energy contents of local rice bran samples were considerably lower than those reported for samples from Australia ${ }^{11}$ and North America., 90 These lower values are related to the high fibre and ash contents of local samples.

The DE content of cassava root meal was found to be similar to that of maize. This finding is in agreement with that of Aumaitre ${ }^{12}$ and highlights the role that cassava root meal could play as a cereal replacer in pig diets. 
Among the protein supplements, soybean meal had the highest DE content $(3.16$ $\mathrm{Kcal} / \mathrm{g}$ ). The DE contents obtained for locally-produced coconut poonac, gingelly poonac and soybean meal were lower than those reported eisewhere., ${ }^{9}$ This discrepancy is due to the relatively high fibre contents of local samples.

The crude protein content of locally-produced fish meal was analysed to be only $41.5 \%$, far below the level of $70.6 \%$ determined for the imported fish meal sample (Table 1). When pigs were fed on diets containing 6.6 and $10 \%$ local fish meal, performance was adversely affected. All animails had watery faeces and lost body weight. The balance trial had to be terminated after the first experimental period. The local fish meal used in the study appeared normal in colour and smell, and there was no evidence of putrefacation. Subsequent analysis showed excessive salt content to be the probable cause for the adverse effects. The sample contained $11.2 \%$ salt, which was much above the legally accepted level of $7 \%{ }^{13}$ The DE content of the imported fish meal was determined to be $3.01 \mathrm{Kcal} / \mathrm{g}$.

The inadequate supplies and rising cost of traditional feedstuffs have focussed attention in the recent past on the need to explore the use of hitherto untapped feed resources. Cassava leaf meal, ipil-ipil leaf meal and poultry litter were evaluated for these reasons. The DE content of these three feedistuffs was estinated to be $2.13,1.54$ and $1.92 \mathrm{Kcal} / \mathrm{g}$, respectively. No comparable data is available or the DE contents of these feed ingredients. Though the nutrient contents of cassava leaf meal and ipil-ipil leaf meal were remarkably similar, the energy digested by pigs was considerably lower (52 vs 38\%) for the ipil-ipil leaf meal. The tannin and mimosine contents of ipil-ipil leaf meal may be responsible for this low digestible energy. ${ }^{3}$

The DE contents reported in this study were obtained using growing pigs. It is noteworthy, however, that the digestion coefficients of feedstuffs, particularly of high-fibre materials, could be expected to be higher for older pigs as reported by Fernandez et al. ${ }^{14}$ in comparative studies with growing pigs and sows. Older pigs have a higher capacity for fermentation and utilization of fibre components in the hindgut than the growing animals.

Published data on the available energy content of feedstuffs of tropical origin are scanty. Consequently pig feed formulations in tropicai countries, including Sri Lanka, have traditionally used DE contents that have been estimated for feedstuffs originating from temperate regions. The results of the present study showed that such usage may not be appropriate, in view of the relatively high fibre contents of tropical feedstuffs. This is particularly true for the agro-industrial by-products which form the feed base for pig production in tropical countries. The data presented will have applications in the formulation of accurate and efficient pig rations in Sri Lanka as well as in other tropical areas where these feed ingredients are commonly used. 


\section{Ackmowledgements}

The study was supported by a NARESA research grant (RG/88/Ag/03). The able technical assistance of Messrs A. Shivakumar and A.R.K. Rajapakse are gratefully acknowledged.

\section{References}

1. Rajaguru A.S.B., Ravindran V. \& Dias E.A. (1978). Utilisation of cassava meal in swine feeding. Journal of the National Science Concil of Sri Lanka 6 (2): 95-102.

2. Ravindran V., Kornegay E.T., Rajaguru A.S.B., Potter L.M. \& Cherry J.A. (1986). Cassava leaf meal as a replacement for coconut oil meal in broiler diets. Poultry Science 65: 1720-1727.

3. Ravindran V. \& Wijesiri C.J. (1988). Leucaena leucocephala leaf meal as an animal feed. I. Composition and feeding vaiue for young chicks. Sri Lankan Journal of Agricultural Science 25: 69-74.

4. May R.W. \& Bell J.M. (1971). Digestible and metabolizable energy values of some feeds for the growing pig. Canadian Joumal of Animal Science 51: 271-278.

5. AOAC. (1975). Official Methods of Analysis. (11th ed.) Association of Official Analytical Chemists, Washington, DC.

6. Ravindran V., Kornegay E.T., Webb Jr K.E. \& Rajaguru A.S.B. (1982). Nutrient characterization of some feedstuffs of Sri Lanka. Joumal of the National Agricultural Society of Sri Lanka 19: 19-32.

7. SAS. (1982). Statistical Analysis System. Statistical Analysis Systems, Inc., Cary, North Carolina, U.S.A.

8. Gohl B. (1981). Tropical Feeds. FAO, Rome.

9. Allen R.M.D. (1991). Ingredient analysis table. Feedstuffs (USA) 63(29): 24-31.

10. NRC. (1979). Nutrient Requirements of Domestic Animals, No.2, Nutrient Requirements of Swine. (8th ed.) National Research Council, National Academy of Sciences, Washington, DC.

11. Warren B.E. \& Farrel D.J. (1990). The nutritive value of full-fat and defatted Australian rice bran. III. The apparent digestible energy content of defatted rice bran in rats and pigs. Animal Feed Science and Technology 27: 247-257.

12. Aumaitre A. (1969). Nutritive value of manioc and different cereals ine early weaning diets for the piglet: digestive utilization of feed and its effects on growth of the animal. Annales de Zootechnie 18: 385-399. 
13. FAO. (1986). The Produciion of Fish Meai and Oil. FAO Fisheries Technical Paper. 142 (Rev. 1), Fisheries Industries Division, Food and Agriculture Organization of the United Nations, Rome.

14. Fernandez J.A., Jorgensen H. \& Just, A. (1986). Comparative digestibility experiments with growing pigs and adult sows. Animal Production 43: 127-132. 